\section{International imperatives}

\author{
Stephen Hancocks OBE \\ Editor-in-Chief
}

Send your comments to the

Editor-in-Chief,

British Dental Journal

64 Wimpole Street,

London

W1G 8YS

Emailbdj@bda.org
The various periodicities of the meetings of three different international dental organisations have created an unusual succession of conferences in the past three months. The International Association of Dental Research (IADR), the International Association of Disability and Oral Health (IADH) and the FDI World Dental Federation have provided the opportunity to study a jigsaw of world dentistry as it heads into the second decade of the century.

Held shortly after the announcement of the 2010 Impact Factors in which the $B D J$ recorded its highest score ever, the IADR meeting in Barcelona found the journal's booth to be the centre of great interest with the added incentive of the newly advertised Shirley Glasstone Hughes Trust Fund's £200,000 grant award to add to the interest. Research remains one of the BDJ's most important areas of content and the good attendance at this meeting, especially by young and talented researchers enabled us to usefully connect with some of the best minds in dental research today. The breadth and depth of dental research at the cutting edge is almost scarily exciting in terms of future delivery of oral care.

The smallest of the conferences, IADH had chosen the Belgian city of Ghent for its biennial gathering of special care dental professionals from over 50 countries. Jammed with ancient buildings which jostle for the visitor's attention, the historic backdrop provided an intriguing contrast to the fully up to date content of the conference as it promoted the practical detail of special care dentistry, the newest of the UK's GDC recognised specialities. There are many times in life that one finds oneself reflecting on the fortune of good health and the tribulations of those not as fortunate. Attending the scientific sessions at IADH really does make one aware of the wide range of disabilities with which people live. Simultaneously, one cannot but be filled with admiration for the practical flexibility and dental dexterity with which special care dentists provide the very best of care in some extremely taxing and occasionally unbelievably challenging situations.

\section{DISAPPOINTING REFLECTIONS}

I am personally and professionally very sad to report that the FDI Annual World Dental Congress was the most disappointing of the three events. Held at the seaside venue of Salvador da Bahia on the Atlantic coast of Brazil, the city did not have the experience or the infrastructure to host what should have been a huge meeting but in fact fell far short of the anticipated attendance. Although the organisers had clearly, personally, done their very best to make the congress a success, the far and away more obvious choices of either Rio de Janeiro or Sao Paulo to the south would have been infinitely preferable and more attractive, despite a robust scientific programme. Indeed the huge national meetings conducted in those cities are reported to regularly attract up to 30,000 of the country's estimated 220,000 dentists, while the FDI languished at less than 5,000.

It pains me considerably to have to write in these terms since my association with the FDI has been continuous since the early 1980s as a writer, editor and publisher. However, in recent times it has been beset with troubles political, financial and organisational having amongst other vagaries 'lost' two Executive Directors and appointed two Interim Executive Directors in a little over three years.

It is often said that if the FDI did not exist it would have to be invented and I would not disagree. The Federation's strengths include its ability to be the worldwide voice of dentistry supported by its more than 100 national member associations, including the BDA. Currently, for example, its representations to the United Nations on the subject of the possible banning of amalgam as a dental restorative material are of the utmost significance. Similarly, its presence in postgraduate education around the world is of great value to the profession and its work in improving oral health in developing countries through its World Dental Development Fund grows in stature and influence.

However, one has to observe that the situation in which the Federation finds itself presently is not good. I hope that as a friend I can voice this, since if in such circumstances allies may not offer positive criticism then the position is serious indeed. It may be that the FDI needs to be reinvented or at least remodelled for the new world in which it finds itself. It has, after all, reached its 110th birthday and it may be that those most concerned about its future can rally together and pave a constructive way forwards. It is my sincerest wish that a pragmatic solution be found, and soon.

The position of British dentistry in all of this is strong and proactive. Our participation at international level is engaged and positive (and not only in the three organisations mentioned above) and despite the almost inhibitory weight of current national bureaucratic nonsense we do still manage to provide world-class patient care. It is important that we remain a continued participant in creating the evolving jigsaw of global dentistry.

DOI: 10.1038/sj.bdj.2010.977 